Copyright (C) 2020 University of Bucharest Printed in Romania. All rights reserved

ISSN print: $1224-5984$

ISSN online: $2248-3942$
Rom Biotechnol Lett. 2020; 25(6): 2027-2032

doi: $10.25083 / \mathrm{rbl} / 25.6 / 2027.2032$

Received for publication, April, 5, 2019

Accepted, December, 27, 2019

Original paper

\title{
The stimulating effects of non-lethal $y$-radiation doses on prokaryotes
}

\author{
IOAN ARDELEAN ${ }^{1, \#, ~ G A B R I E L A ~ T E O D O S I U ~}{ }^{1, \#, ~ M U G U R ~ S ̧ T E F A ̆ N E S C U ~}{ }^{1}$, \\ CRISTINA MOISESCU ${ }^{1}$, ANA-VALENTINA ARDELEAN ${ }^{1,2}$, MARIAN \\ CONSTANTIN $^{1,3, *}$, DOINA MARIA CÎRSTEA ${ }^{1,3}$ \\ ${ }^{1}$ Institute of Biology Bucharest, Romanian Academy, 296 Splaiul Independentei, 060031, \\ Bucharest, Romania \\ ${ }^{2}$ University of Agronomic Sciences and Veterinary Medicine of Bucharest, 59 Mărăşti \\ Boulevard, District 1, Bucharest, 011464, Faculty of Biotechnology, Romania \\ ${ }^{3}$ The Research Institute of the University of Bucharest, ICUB, Bucharest, Romania \\ "Ioan Ardelean and Gabriela Teodosiu contributed equally to this paper
}

\begin{abstract}
The aim of this paper is to review the published results on the interaction between prokaryotes, both Archaea and Bacteria, with $\gamma$-irradiation at doses which do not inhibit cellular growth or cell multiplication. Special emphasis is on the ability of $\gamma$-radiation to stimulate cell metabolism, one applicative task being the synthesis of useful compounds both for the cells and for practical applications, such as biotechnological and medical uses.
\end{abstract}

Keywords $\gamma$-irradiation, non-inhibitory doses, Archaea, bacteria, cyanobateria, carotenoids pigments, biosurfactants, polyhydroxybutyrate.

To cite this article: ARDELEAN I, TEODOSIU G, ŞTEFĂNESCU M, MOISESCU C, ARDELEAN AV, CONSTANTIN M, CÎRSTEA DM. The stimulating effects of non-lethal $\gamma$-radiation doses on prokaryotes. Rom Biotechnol Lett. 2020; 25(6): 2027-2032. DOI: $10.25083 / \mathrm{rbl} / 25.6 / 2027.2032$

*Corresponding author: MARIAN CONSTANTIN, Institute of Biology Bucharest, Romanian Academy, Romania, The Research Institute of the University of Bucharest, ICUB, Bucharest, Romania E-mail: cvgmarian@gmail.com 


\section{Introduction}

Radiation is energy in the form of particles. There are two types of radiation: non-ionizing, which has lower energy, lower frequency and longer wavelength (e.g., earth magnetic field, radio waves, microwaves, infrared waves, visible light and some sunrays) and ionizing, which can knock the electrons out their orbits around atoms, giving the atoms a positive charge and has higher energy, higher frequency and shorter wavelength (e.g., alpha radiation, consisting of two protons and two neutrons, carrying a double positive charge, beta radiation, consisting of negative particles ejected from atom's nucleus, photon radiation, originating from nucleus, as gamma rays, and outside of nucleus, as X-rays, and neutron radiation, which results from spontaneous fission and cosmic interactions) (CNSC, 2012) [1]. The interaction between different types of microorganisms and $\gamma$-irradiation is a well-established topic for high doses which inhibit cellular growth and cell multiplication, causing massive cell death (BRIDGES, 1971 [2], HANSEN \& SHAFFER (2001) [3], CHOI et al, 2014 [4], LIU et al, 2015 [5]). Interestingly, the work at low doses receives less attention as compared with inhibitory doses, and up to our best knowledge there is only one review published more than 4 decades ago (PLANEL et al [6]). However, in recent years, there has been an increasing interest in using relatively low doses of $\gamma$-radiation to stimulate biological processes in different types of microorganisms. The aim of this paper is to present the state of the art on the interaction between prokaryotes, both Archaea and Bacteria, with $\gamma$-irradiation at doses which do not inhibit cellular growth or cell multiplication.

\section{Effect of $\gamma$-radiation on the Archaea strains}

Among the microorganisms, halophilic Archaea strains showed an increased resistance to $\gamma$-radiation than other prokaryotes. The halophiles group consists of different microorganisms adapted to the presence of salts in the living environment. Extreme halophilic microorganisms inhabit salty environments with very high concentration of $\mathrm{NaCl}$, sometimes up to saturation point (e.g., extremophilic species of the Archaea domain, known as haloarchaea, are adapted to $\mathrm{NaCl}$ concentrations up to 4M) (OREN, [7], [8], GUPTA et al [9], RODRIGO-BAÑOS et al [10]). In order to survive and grow in the extreme conditions of the hypersaline habitats, the haloarchaea members developed various adaptation mechanisms, including increase of the synthesis of some biocompounds (TORREGROSACRESPO et al [11]), such as proteins/enzymes, carotenoid pigments, bacteriorhodopsin, polyhydroxyalkanoates/ polyhydroxybutyrate and halocins (bacteriocin-like peptides), used by scientists from various domains of biotechnology and biomedicine (ELLEUCHE et al [12], ALSAFADI and AL-MASHAQBEH [13]). Biosynthesis of carotenoid pigments, peculiarly derivatives of bacterioruberin, $\beta$-carotene, lycopene, phytoene and salinixanthin (DE LOURDES MORENO et al [14], EL-SAYED et al [15], YATSUNAMI et al [16]; RODRIGO-BAÑOS et al [10]), is of particular interest because most of their biotechnological applications, but especially their impact on human health (JEHLICKA et al [17], FIEDOR AND BURDA, [18], TORREGROSA-CRESPO et al [11]). Carotenoid pigments are usually components of haloarchaeal cell membranes, offer the cells characteristic colors (pink, red, orange, purple) and provides protection against ionizing radiations (KISH et al [19], RODRIGO-BAÑOS et al [10], SHIRSALIMIAN et al [20]) in a manner depending to the catena length and the number of conjugated double bonds in it. Bacterioruberin, a C50 carotenoid pigment with 13 conjugated double bonds, is involved in reinforcement of cell membrane, has a higher capacity to protect cells against oxidative stress, UV and $\gamma$-radiation, than $\beta$-carotene, a C50 carotenoid pigment with only 9 conjugated double bonds (RODRIGO-BAÑOS M. [10]).

On Archaea, the studies were focused on isolation and characterization of carotenoid pigments (RONNEKLEIV and LIAAEN-JENSEN, [21]) and the influence of various environmental factors on their biosynthesis (EL-SAYED et al [15]; D'SOUZA et al [22]). Previous studies (KOTTEMANN et al [23]) showed that halophilic archaea strains belonging to Halobacterium genus exposed to ${ }^{60} \mathrm{Co} \gamma$-ray irradiation had no distinct loss of viability between $0.5 \mathrm{kGy}$ and $2.5 \mathrm{kGy}$. The resistance of Halobacterium to $\gamma$-rays is growth phase-dependent, becoming more sensitive in stationary phase (OD600 $\mathrm{nm}>1.0$ ) than exponential growing cultures (KOTTEMANN et al [23]), possibly due to higher efficiency in ROS removal in actively growing cells. Gamma rays ionize water and generate ROS, which interact with intracellular macromolecules, causing damages and activating cellular pathways for repairing them, including DNA-repairing mechanisms, inorganic scavengers (e.g., salts and $\mathrm{Mn}^{++}$ ions) and organic scavengers (carotenoids and ROS scavenging enzymes). ROS are also neutralized by intracellular halides, especially $\mathrm{KCl}$ and bromides, protecting the cells against nucleotide modification and carbonylation of protein residues (SHAHMOHAMMADI et al [24], KISH et al [19], ASGARANI et al [25]).

\section{Effect of $\gamma$-radiation on the Bacteria strains}

The study of the effects of $\gamma$-irradiation on bacteria started more than 80 years ago on different topics such as the resistance of the cells to radiation (up to mutagenic and lethal doses), the use of irradiation to inactivate bacteria including the sterilization of products for different purposes as well as the stimulation of the synthesis of certain metabolic products. Also, in the literature there are various studies related to the stimulation aspect of $\gamma$-radiation on different bacterial metabolites. Luo's 1998 [26] studies on poly (hydroxybutyrate-hydroxyvalerate) (PHBV) on the effects of radiation on chemical, mechanical and thermal properties found a decrease in these properties. 
Bacillus strains. Divyashree and Shamala, 2009 [27], argue that irradiation of the Bacillus flexus strain does not greatly affect the quality of hydroxybutyrate/ hydroxyalkanoate. The strain of Bacillus subtilis UTB1, subjected to $\gamma$-irradiation (100 Gray to 3000 Gray), has led to the emergence of variants with stronger antimycotic activity in vitro, overproduction of biosurfactants and more robust biofilms. The wild bacterial strain, Bacillus subtilis UTB1, synthesizes a reduced amount of surfactant compared to the variants mutants (M419, M425, M455, M464, M497, M525, M562 and M600) obtained by the irradiation, confirmed by the tests lyse blood agar and oil spreading technique (AFSHARMANESH et al, 2013) [28].

Pseudomonas strains. The irradiation of the Pseudomonas aeruginosa strain to $300 \mathrm{~Gy}$ resulted in the variant, Pseudomonas aeruginosa MR01-C, this mutant has the ability of the hyperproduction of biosurfactants in MS minimal medium. This strain synthesized an increased amount of biosurfactant as compared to the control sample, showed a rise in di-rhamnolipide from the sample to $88.6 \% *(15 \%$ greater than the control) and the amount of Rha-Rha-C10-C10 increased to 52.08\% ( 45\% higher than control) (LOTFABAD et al, 2010) [29]. Iqbal, 1995 [30], reports getting a mutant of Pseudomonas aeruginosa strain S8, obtained by $\gamma$-irradiation to 300-400 Gy. This microorganism is capable of hyperproduction of biosurfactant, that biosurfactant production has increased two to threefold using $\gamma$-ray mutagenesis. Furthermore, mutant strain emulsified crude oil much faster than parent.

Cyanobacteria strains. In the Synechococcus lividus (COUNTER et al, 1986 [31] have shown that very low chronic doses of $\gamma$-radiation $(53.5 \mathrm{mGy} /$ year) can stimulate proliferation of the cells, induced a high superoxide dismutase (SOD) activity followed by concomitant peaks of glutathione reductase (GR) and glucose-6-phosphate dehydrogenase (G6P-DH). Furthermore, there is an increase in pigment content and an enhancement of glyceraldehyde-3-phosphate dehydrogenase (GAP-DH) and the degradation of phycocyanin, thus demonstrating that cells were submitted to a photooxidative stress. Later on, (COUNTER et al, 1987 [32]) also demonstrated that chronic $\gamma$-irradiation with doses ranging from $0.058 \mathrm{mGy} /$ day to $0.204 \mathrm{mGy} /$ day had a stimulatory effect on nucleic acid synthesis and induced an increase in SOD, GR and G6P-DH as a response to the oxidative stress. HU et al [33] reported that low doses of $\gamma$-rays, less than $1 \mathrm{kGy}$, could stimulate the growth of A. platensis. Small changes in the morphology of the filament were found at doses less than $0.5 \mathrm{kGy}$. The $\mathrm{LD}_{50}$ was $1.0 \mathrm{kGy}$, while $2.5 \mathrm{kGy}$ caused $100 \%$ lethality. WANG et al (1998) [34] studied the effect of $\gamma$-radiation (up to $6 \mathrm{kGy}$ ) on the growth and morphology of four different strains of Arthrospira sp. and concluded that it showed resistance to $\gamma$-irradiation with stimulation of growth at low doses, while the filaments would break up or even disintegrate at high doses. Although many studies have evaluated the biological response of cyanobacteria to high doses of $\gamma$-radiation, few studies have focused on stimulation of bioactive compounds production in A. platensis. RAZI and HASNAIN 2006, [35] studied the effect of $\gamma$-rays on the growth parameters of two chromium resistant unicellular cyanobacteria, from the genus Synechocystis sp. Both strains showed a significant increase in chlorophyll content when irradiated at doses of 1 to $10 \mathrm{~Gy}$. Carotenoid content increased significantly only in AHZ-HB-MK (DQ381960) sp. at all growth stages. MOUSSA et al. (2015), [36] exposed A. platensis to different $\gamma$-radiation doses $(0.5,1.0,1.5,2.0,2.5$, and $3.0 \mathrm{kGy})$ and found that the optimum upsurge for chlorophyll $a$, carotenoids, intensity of total photosynthetic activity, and carbohydrates is at $2.0 \mathrm{kGy}$. Ribuloso-1,5-bisphosphate carboxylase / oxygenase (RUBISCO) activity peaked at $2.0 \mathrm{kGy}$ and phosphoenol-pyruvate-carboxylase activity (PEPCASE) peaked at $1.0 \mathrm{kGy}$. Another important study, (BADRI et al, 2015) [37] showed that Arthrospira sp. PCC 8005 is highly tolerant to $\gamma$-rays and can survive to at least $6400 \mathrm{~Gy}$ (dose rate of $527 \mathrm{~Gy} / \mathrm{h}$ ). Their detailed proteomic and transcriptomic analyses performed after irradiation with 3200 or 5000 Gy showed a decline in photosystem II quantum yield, reduced carbon fixation, and reduced pigment, lipid, and secondary metabolite synthesis. On the other hand, transcription of photo-sensing and signalling pathways, and thiol-based antioxidant systems was induced. Furthermore, transcriptomics did show significant activation of ssDNA repair systems and mobile genetic elements (MGEs) at the RNA level. Interestingly, the cells did not induce the classical antioxidant or DNA repair systems, such as superoxide dismutase (SOD) enzyme and the RecA protein. Arthrospira sp. cells lack the catalase gene and the LexA repressor. Based on the observation that irradiated Arthrospira cells did induced strongly a group of conserved proteins, the authors (BADRI et al, 2015) put forward the hypothesis that these proteins could be involved in the response of cyanobacterial cells to irradiation, which remains to be checked. ABOMOHRA et al (2016) [38] showed that in the cyanobacterium Arthrospira platensis carbohydrate production by 106, 246 and 146\%, respectively and lipid content increased significantly over the control at $0.5 \mathrm{kGy}$. Interestingly, carotenoid productivity showed significant increase at all used $\gamma$-rays doses up to $155 \%$ over the control whereas other components decreased.

SHABANA et al (2017) [39] showed that in A. platensis exposed to doses up to $2.0 \mathrm{kGy}$, significantly increased the phenolic and proline contents and stimulated the soluble proteins, malondialdehyde (MDA), vitamins (A, K and $\mathrm{B}$ group) and mineral $(\mathrm{N}, \mathrm{P}, \mathrm{Na}, \mathrm{K}, \mathrm{Ca}, \mathrm{Mg}$ and $\mathrm{Fe}$ ) contents. The activities of some $\mathrm{N}$-assimilating and antioxidant enzymes were significantly increased at irradiation doses up to $2.0 \mathrm{kGy}$. This study withstands the possible use of $\gamma$-irradiation as a stimulatory agent to raise the nutritive value and antioxidant activity of A. platensis. 
Gamma rays ionize water and generate ROS (reactive oxygen species, which include hydrogen peroxide, $\mathrm{H}_{2} \mathrm{O}_{2}$, superoxide, $\mathrm{O}_{2}^{-}$, and hydroxyl radicals, $\mathrm{HO}^{-}$) which interact with intracellular macromolecules, causing damages and activating cellular pathways for repairing them (ROBINSON et al [40]). The higher the dose of $\gamma$-radiation penetrates the cell, the greater the amplitude of damages and the complexity of repairing mechanisms, including DNA-repairing mechanisms, inorganic scavengers (e.g., salts and $\mathrm{Mn}^{++}$ions) and organic scavengers (carotenoids and ROS scavenging enzymes). ROS and
ROS-altered cellular compunds could interact with members of signaling pathways to induce changes in some gene expression, as suggested by TALE et al, 2017 [41]), for up regulation of lipid biosynthetic pathway, and by BADRI et al, 2015 [37]), for a group of conserved proteins. We expect that the $\gamma$-irradiation at low doses could increase synthesis of some compounds important for cell biology and for biotechnological and medical applications.

In Table 1 there are presented the main results reported on stimulating effects of non-lethal $\gamma$-radiation doses on Archaea and Bacteria.

Table 1. Syntethic presentation of some archaean and bacterial strains where $\gamma$-irradiation stimulates metabolism (for more explications, please see the text)

\begin{tabular}{|c|c|c|c|}
\hline Strain & Irradiation & Results & Authors \\
\hline $\begin{array}{l}\text { Halobacterium salinarum } \\
\text { NRC-1 (ATCC 700922) }\end{array}$ & $2.5-7.5 \mathrm{kGy}$ & $\begin{array}{l}\text { No distinct loss of viability up to } 2.5 \mathrm{kGy} \\
\text { (D10 to } 5 \mathrm{kGy} \text { ); increased sensitivity to } \\
\text { irradiation in stationary phase. }\end{array}$ & $\begin{array}{l}\text { Kottemann et al, } \\
2005\end{array}$ \\
\hline $\begin{array}{l}\text { Haloferax } \\
\text { radiotolerans (IRU) }\end{array}$ & $0.5 \mathrm{~Gy} / \mathrm{s}$ & $\begin{array}{l}\text { The resistance of Haloferax IRU to } \\
\gamma \text { irradiation - partly attributable to high } \\
\text { intracellular } \mathrm{KCl} \text { and bacterioruberin. }\end{array}$ & Asgarani et al, 2006 \\
\hline $\begin{array}{l}\text { Halobacterium } \\
\text { salinarum NRC } 34002\end{array}$ & $3 \mathrm{~Gy} / \mathrm{min}$ & Bacterioruberin protection to $\gamma$ rays. & $\begin{array}{l}\text { Shahmohammadi et } \\
\text { al, } 1997\end{array}$ \\
\hline Synechococcus lividus & $\begin{array}{l}\text { chronic } \\
\gamma \text {-irradiation }\end{array}$ & $\begin{array}{l}\text { Increased growth rate and of some } \\
\text { enzymatic activities }\end{array}$ & $\begin{array}{l}\text { Conter et al, 1986, } \\
1987\end{array}$ \\
\hline A. platensis. & $\begin{array}{l}0.5 \mathrm{kGy}- \\
3.0 \mathrm{kGy}\end{array}$ & At lower irradiation growth is stimulated & Hu et al, 1990 \\
\hline Arthrospira sp & up to $6 \mathrm{kGy}$ & At low irradiation the growth is stimulated & Wang et al, 1998 \\
\hline Arthrospira sp. PCC 8005 & 3.2 or $5 \mathrm{kGy}$ & $\begin{array}{l}\text { Detailed proteomic and transcriptomic } \\
\text { analyses }\end{array}$ & Badri et al, 2015 \\
\hline Arthrospira platensis & $\begin{array}{l}0.5 \mathrm{kGy}- \\
2.5 \mathrm{kGy}\end{array}$ & $\begin{array}{l}\text { Stimulatory effects at } 0.5 \text { Gy and } \\
\text { inhibitory ones at higher density }\end{array}$ & $\begin{array}{l}\text { Abomohra et al, } \\
(2016)\end{array}$ \\
\hline A. platensis & $\begin{array}{l}\text { doses up to } \\
2 \mathrm{kGy}\end{array}$ & $\begin{array}{l}\text { Increased content of soluble proteins, } \\
\text { vitamins and minerals }\end{array}$ & Shabana et al, 2017 \\
\hline Pseudomonas aeruginosa. & $0.3-0.4 \mathrm{kGy}$ & hyperproduction of biosurfactants & Iqbal et al, 1995 \\
\hline Bacillus subtilis UTB1 & $0.1-3 \mathrm{kGy}$ & $\begin{array}{l}\text { biosurfactants and more robust biofilms } \\
\text { Afsharmanesh et al, } 2013\end{array}$ & $\begin{array}{l}\text { Afsharmanesh et } \\
\text { al, } 2013\end{array}$ \\
\hline $\begin{array}{l}\text { Pseudomonas aeruginosa } \\
\text { MR01-C }\end{array}$ & $0.3 \mathrm{kGy}$ & increased amount of biosurfactant & Lotfabad et al, 2010 \\
\hline
\end{tabular}

\section{Conclusions}

The content of this review argue that, at international level, the topic is under increased interest. The results rewieved in this paper show that the use of non lethal gamma irradition on prokaryotic cells, both Archaea and Bacteria, could stimulate, in some cases, the synthesis of various metabolic products. All these changes are important indices toward understanding the mechanisms involved in the control of their synthesis, wheres some of them concerns metabolites which are of biotechnological significance as well (biosurfactants and PHA, carotens, lipids etc.)

\section{Research perspectives}

The perspectives of this domain concerns both biotechnological and fundamental research. With respect to applications: i) The use of bacterial strains, including those isolated from contaminated area, and able to produce metabolits in excess following gamma irradiation with biotechnological potential; ii) the cultivation of the selected prokaryotes/microorganisms on minimal media or as cheap as possible ones, eventually based on waste products as well; iii) diversification of researches concerning the characterization and the utility of biologic active products represent the first interest for the implementation the biologic methods in various technologies. 


\section{Aknowledgements}

This work was funded by the PN-III-P1-1.2PCCDI2017-0323 Project "Utilization of Gamma irradiation in biotechnological processes with applications in bioeconomy".

\section{References}

1. Canadian Nuclear Safety Commission (CNSC). Introduction to Radiation (2012).

2. B.A. BRIDGES. RecA+-dependent repair of gammaray damage to Escherichia coli does not require recombination between existing homologous chromosomes. J Bacterial, 108, 944-945 (1971).

3. J.M. HANSEN \& H.L. SHAFFER. Sterilization and preservation by radiation sterilization. In Disinfection, Sterilization and Preservation, pp. 729-746. Edited by S. S. Block. Philadelphia, PA: Lippincott Williams \& Wilkins (2001).

4. J. CHOI, M. YOON, M. JOE, H. PARK, S.G. LEE, S.J. HAN, P.C. LEE. Development of microalga Scenedesmus dimorphus mutant with higher lipid content by radiation breeding. Bioprocess Biosyst Eng 37:2437-2444 (2014).

5. B. LIU, C. MA, R. XIAO, D. XING, H. REN, N. REN. The screening of microalgae mutant strain Scenedesmus sp. Z-4 with a rich lipid content obtained by 60Co $\gamma$-ray mutation. RSC Adv 5:52057-52061 (2015).

6. H. PLANEL, J.P. SOLEILHAVOUP, R. TIXADOR, F. CROUTE, G. RICHOIUEY. Demonstration of a stimulating effect of natural ionizing radiation and of very low radiation doses on cell multiplication. International Atomic Energy Agency STI/PUB/409: 127-140 (1976).

7. A. OREN. Industrial and environmental applications of halophilic microorganisms. Environ.Technol., 31, 825-834 (2010).

8. A. OREN. Halophilic archaea on Earth and in space: Growth and survival under extreme conditions. Philos. Trans. A Math. Phys. Eng. Sci., 13, 372 (2014).

9. R.S.GUPTA, S. NAUSHAD, S. BAKER. Phylogenomic analyses and molecular signatures for the class Halobacteria and its two major clades: A proposal for division of the class Halobacteria into an emended order Halobacteriales and two new orders, Haloferacales ord nov and Natrialbales ord. nov., containing the novel families Haloferacaceae fam. nov. and Natrialbaceae fam. nov. Int. J. Syst. Evol. Microbiol., 65, 1050-1069 (2015).

10. M. RODRIGO-BAÑOS, I. GARBAYO, C. VÍLCHEZ, M.J. BONETE, \& R.M. MARTÍNEZ-ESPINOSA. Carotenoids from Haloarchaea and Their Potential in Biotechnology. Marine drugs, 13(9), 5508-5532 (2015). doi:10.3390/md13095508

11. J. TORREGROSA-CRESPO, P.G. CARMEN and M.-E. ROSA MARÍA. Biocompounds from Haloarchaea and Their Uses in Biotechnology. In: Archaea - New Biocatalysts, Novel Pharmaceuticals and Various Biotechnological Applications, chapter 4, pp. 63-82 (2017).

12. S. ELLEUCHE, C. SCHÄFERS, S. BLANK, C. SCHRÖDER, G. ANTRANIKIAN. Exploration of extremophiles for high temperature biotechnological processes. Current Opinion in Microbiology, 25:113119 (2015).

13. D. ALSAFADI, O. AL-MASHAQBEH. A one-stage cultivation process for the production of poly-3(hydroxybutyrate-co-hydroxyvalerate) from olive mill wastewater by Haloferaxmediterranei. New Biotechnology, 34: 47-53 (2017).

14. M. DE LOURDES MORENO, C. SÁNCHEZPORRO, M.T. GARCÍA, E. MELLADO. Carotenoids' production from halophilic bacteria. Methods Mol. Biol., 892, 207-217 (2012).

15. W.S. EL-SAYED, S. TAKAICHI, H. SAIDA, M. KAMEKURA, M. ABU-SHADY, H. SEKI, T. KUWABARA. Effects of light and low oxygen tension on pigment biosynthesis in Halobacterium salinarum, revealed by a novel method to quantify both retinal and carotenoids. Plant \& Cell Physiology, 43: 379-383 (2002).

16. R. YATSUNAMI, A. ANDO, Y. YANG, S. TAKAICHI, M. KOHNO, Y. MATSUMURA, H. IKEDA, T. FUKUI, K. NAKASONE, N. FUJITA, M. SEKINE, T. TAKASHINA, S. NAKAMURA. Identification of carotenoids from the extremely halophilic archaeon Haloarcula japonica. Frontiers in Microbiology, 5: 100-105 (2014).

17. J. JEHLICKA, H.G. EDWARDS, A. OREN. Bacterioruberin and salinixanthin carotenoids of extremely halophilic archaea and bacteria: A Raman spectroscopic study. Spectrochimica Acta, Part A: Molecular and Biomolecular Spectroscopy, 106: 99-103 (2013).

18. J. FIEDOR, K. BURDA. Potential role of carotenoids as antioxidants in human health and disease. Nutrients, 6: 466-488 (2014).

19. A. KISH, G. KIRKALI, C. ROBINSON, R. ROSENBLATT, P. JARUGA, M. DIZDAROGLU, J. DIRUGGIERO. Salt shield: intracellular salts provide cellular protection against ionizing radiation in the halophilic archaeon, Halobacterium salinarum NRC-1, Environ Microbiol. 11(5):1066-78 (2009).

20. SHIRSALIMIAN M.S., AMOOZEGAR M.A., AKHAVAN SEPAHY A., KALANTAR S.M., DABBAGH R. (2017). Isolation of Extremely Halophilic Archaea from a Saline River in the Lut Desert of Iran, Moderately Resistant to Desiccation and Gamma Radiation. Microbiology, 86: 403. https://doi.org/10.1134/S0026261717030158

21. M. RONNEKLEIV, S. LIAAEN-JENSEN. Bacterial Carotenoids 53*, C50-Carotenoids 23; Carotenoids of Haloferax volcanii versus other Halophilic Bacteria. Biochem. Syst. Ecol. 23, 627-734 (1995). 
22. S.E. D'SOUZA, W. ALTEKAR, S.F. D'SOUZA. Adaptive response of Haloferax mediterranei to low concentrations of $\mathrm{NaCl}(<20 \%)$ in the growth medium. Archives of Microbiology, 168:68-71 (1997).

23. M. KOTTEMANN, A. KISH, C. ILOANUSI, S. BJORK, J. DIRUGGIERO. Physiological responses of the halophilic archaeon Halobacterium sp. strain NRC1 to desiccation and gamma irradiation, Extremophiles. 9(3):219-27. Epub 2005 Apr 21 (2005).

24. H.R. SHAHMOHAMMADI, E. ASGARANI, H. TERATO, H. IDE, O. YAMAMOTO. Effects of ${ }^{60} \mathrm{Co}$ gamma-rays, ultraviolet light, and mitomycin $\mathrm{C}$ on Halobacterium salinarium and Thiobacillus intermedius. J Radiat Res. 38(1):37-43 (1997).

25. E. ASGARANI, M. SHIRZAD, M. SOUDI, H. SHAHMOHAMMADI. Study On The Effects Of ${ }^{60} \mathrm{Co}$ Gamma-Rays, Ultraviolet Light (UV), And Hydrogen Peroxide On Haloferax IRU. The Internet Journal of Microbiology. Volume 3, Number 1 (2006).

26. S. LUO, A. N. NETRAVALI. Effect of ${ }^{60} \mathrm{Co}$ g-Radiation on the Properties of Poly(hydroxybutyrateco-hydroxyvalerate), Journal of Applied Polymer Science, vol. 73, 1059-1067 (1998).

27. M.S. DIVYASHREE, T.R. SHAMALA. Effect of gamma irradiationon cell lysis and polyhydroxyalkanoate producedby Bacillus flexus, Radiation Physics and Chemistry, 78 147-152 (2009).

28. H. AFSHARMANESHA, M. AHMADZADEHA, A. MAJDABADI, F. MOTAMEDIB, K. BEHBOUDIA and M. JAVAN-NIKKHAHA. Enhancement of biosurfactants and biofilm production after gamma irradiation-induced mutagenesis of Bacillus subtilis UTB1, a biocontrol agent of Aspergillus flavus, Archives of Phytopathology and Plant Protection, Vol. 46, No. 15, 1874-1884, http://dx.doi.org/10.1080/ 03235408.2013 .780374 (2013).

29. T.B. LOTFABAD, H. ABASSIB, R. AHMADKHANIHAC, R. ROOSTAAZADA, F. MASOOMIB, H.S. ZAHIRIB, G. AHMADIANB, H.VALI, K.A. NOGHABIB. Structural characterization of a rhamnolipid-type biosurfactant produced by Pseudomonas aeruginosa MR01: Enhancement of di-rhamnolipid proportion using gamma irradiation, Colloids and Surfaces B: Biointerfaces 81:397-405 (2010).

30. S. IQBAL, Z.M. KHALLD and K.A. MALIK. Enhanced biodegradation and emulsification of crude oil and hyperproduction of biosurfactants by a gamma ray-induced mutant of Pseudomonas aeruginosa, Letters in Applied Microbiology, 21, 176-179 (1995).

31. A. CONTER, D. DUPOUY, C. DELTEIL, H. PLANEL. Influence of very low doses of ionizing radiation on Synechococcus lividus metabolism during the initial growth phase. Arch Microbiol 144(3): 286-290 (1986).

32. A. CONTER, D. DupouY, C. VincENT, H. PLANEL. Radiation stimulation during the early stationary growth phase in Synechococcus lividus and its correlation with photooxidative stress occurring before the stationary phase. Health Phys. 1987 Sep; 53(3):281-6 (1987).

33. T. HU, S. YANG, Y. MAO. The effect of $\gamma$-irradiation on Spirulina platensis. Acta Agriculturae Nucleatae Sinica, 4(2): 120-124 (1990).

34. Z. WANG, B. XU, X. ZHAO, J. JIANG, S. CHEN. The effect of gamma-irradiation on different strains and morphological filaments of Spirulina. Acta Agriculturae Universitatis Zhejiangensis; 24(02): 121-125 (1998).

35. S.RAZI, S. HASNAIN, Gamma Irradiation: Impact on Chromate Resistant Cyanobacteria. Science Asia 32 Supplement 1: 107-111. doi: 10.2306/scienceasia15131874.2006.32(s1).107 (2006).

36. H. BADRI, P. MONSIEURS, I. CONINX, R. WATTIEZ, N. LEYS. Molecular investigation of the radiation resistance of edible cyanobacterium Arthrospira sp. PCC 8005. Microbiology Open, 4, 187-207 (2015).

37. H.R. MOUSSA, M.M.S. ISMAIEL, E.F. SHABANA, M.A. GABR and E.A. EL-SHAER. The Role of Gamma Irradiation on Growth and Some Metabolic Activities of Spirulina platensis J. Nucl. Tech. Appl. Sci, vol. 3, no. 2, pp. 99: 107 (2015).

38. A.E.-F. ABOMOHRA, W. EL-SHOUNY, M. SHARAF, M. ABO-ELENEEN, 2016. Effect of gamma radiation on growth and metabolic activities of Arthrospira platensis. Braz. Arch. Biol. Technol. 59: e16150476

39. E.F. SHABAN, M.A. GABR, H.R. MOUSSA, E.A. EL-SHAER, M.S. ISMAIEL. Biochemical composition and antioxidant activities of Arthrospira (Spirulina) platensis in response to gamma irradiation. Food Chemistry 214 (2017) 550-555 (2017).

40. C.K. ROBINSON, K. WEBB, A. KAUR, P. JARUGA, M. DIZDAROGLU, N.S. BALIGA, A. PLACE, J. DIRUGGIERO. A major role for nonenzymatic antioxidant processes in the radioresistance of Halobacterium salinarum. Journal of bacteriology, 193(7), 1653-1662 (2011). doi:10.1128/JB.01310-1.

41. P.M. TALE, R. SINGH, P.B. KAPADNIS, B.S. GHOSH. Effect of gamma irradiation on lipid accumulation and expression of regulatory genes involved in lipid biosynthesis in Chlorella sp. J. Appl. Phycol. 30: 277 (2017). https://doi.org/10.1007/s10811-0171229-9 